\title{
Application of Wet vs. Microwave Digestion for Trace Element Determination in Soil, Vegetable, Nuts, and Grain Samples by ICP-OES
}

\author{
Huseyin Altundag ${ }^{a *}$, Sinem Albayrak ${ }^{a}$, Mustafa S. Dundar ${ }^{a}$, Mustafa Tuzen ${ }^{b}$, and Mustafa Soylak ${ }^{\mathrm{c}}$ \\ a Sakarya University, Faculty of Arts and Sciences, Department of Chemistry, 54187 Sakarya, Turkey \\ ${ }^{b}$ Gaziosmanpasa University, Faculty of Arts and Sciences, Chemistry Department, 60250 Tokat, Turkey \\ c Erciyes University, Faculty of Science, Chemistry Department, 38039 Kayseri, Turkey
}

\section{INTRODUCTION}

The trace elements $\mathrm{Co}, \mathrm{Cr}, \mathrm{Cu}$, $\mathrm{Fe}, \mathrm{Mn}, \mathrm{Ni}, \mathrm{Se}$, and $\mathrm{Zn}$ are known to be one of the main sources of environmental pollution and greatly influence ecological quality (1-2). These problems are due to irrigation with contaminated water, application of pesticides and fertilizers, industrial emission, transport, harvesting, storage, and in the distribution process of foods (3-5).

Trace elements are present at low concentrations in most soils, plants, and living organisms and are important for daily nutrition; however, they become hazardous in excess amounts (6-7). For instance, $\mathrm{Co}, \mathrm{Cu}, \mathrm{Fe}, \mathrm{Mn}, \mathrm{Se}$, and $\mathrm{Zn}$ are essential for the normal growth of plants and the human organism, while $\mathrm{Cr}$ and $\mathrm{Ni}$ are hazardous when present in excess in soil, water, and foods (8-10).

Fruits and leafy vegetables contain trace elements because of their high water content (11). Nutritional information is of importance to agricultural industries to maintain freshness of produce. Consumers are asking for diversity in their diets and are also aware of the health benefits of fruits and vegetables. Most nutritional requirements can be satisfied by the consumption of fruits and vegetables from 5-13 servings day ${ }^{-1}(12)$. It has also been reported (13-15) that eating more fruits and vegetables $\left(>400 \mathrm{~g} \mathrm{day}^{-1}\right)$ is related to a reduced risk of car-

\section{*Corresponding authors.}

E-mail: altundag@sakarya.edu.tr,

E-mail: mustafa.tuzen@gop.edu.tr

Tel:: +90.2642956059

Fax: +90.2642955950

\section{ABSTRACT}

In this study, the ICP-OES determination of the trace elements $\mathrm{Co}, \mathrm{Cr}, \mathrm{Cu}, \mathrm{Fe}, \mathrm{Mn}, \mathrm{Ni}, \mathrm{Se}$, and $\mathrm{Zn}$ in soil, vegetable, nuts and grain samples from Sakarya, Turkey, was evaluated after wet and microwave digestion. Element concentrations found in the soil samples were $0.6-1.7$ $\mu \mathrm{g} \mathrm{g}^{-1}$ (Co), 4.2-8.5 $\mu \mathrm{g} \mathrm{g}^{-1}$ (Cr), 2.5-8.5 $\mu \mathrm{g} \mathrm{g}^{-1}(\mathrm{Cu}), 46.2-69.9$ $\mu \mathrm{g} \mathrm{g}^{-1}(\mathrm{Mn}), 4.7-7.6 \mu \mathrm{g} \mathrm{g}^{-1}(\mathrm{Ni})$, and 5.3-9.4 $\left.\mu^{-1} \mathrm{~g}^{-1} \mathrm{Zn}\right)$; in the vegetable samples $0.2-1.1 \mu \mathrm{g} \mathrm{g}^{-1}$ (Cu), 27.2-114.6 $\mathrm{gg} \mathrm{g}^{-1}$ (Fe), 3.8-6.5 $\mu \mathrm{g} \mathrm{g}^{-1}(\mathrm{Mn})$, and 2.1-8.9 $\mu \mathrm{g} \mathrm{g}^{-1}(\mathrm{Zn})$; and in the dried food samples 0.04-0.94 $\mu \mathrm{g} \mathrm{g}^{-1}$ (Co), 0.24-5.64 $\mu \mathrm{g} \mathrm{g}^{-1}$ (Cr), 2.55-15.92 $\mu \mathrm{g} \mathrm{g}^{-1}(\mathrm{Cu}), 4.82-37.55 \mu \mathrm{g} \mathrm{g}^{-1}$ (Fe), 1.12-30.17 $\mathrm{\mu g} \mathrm{g}^{-1}$ (Mn), $0.43-2.27 \mu \mathrm{g} \mathrm{g}^{-1}(\mathrm{Ni}), 0.03-0.94$ $\mu \mathrm{g} \mathrm{g}^{-1}$, (Se) and 2.93-20.91 $\mu \mathrm{g} \mathrm{g}^{-1}$ ( $\mathrm{Zn})$. The accuracy of the method was verified using certified reference materials NIST CRM 7001 Light Sandy Soil and NIST SRM 1515 Apple Leaves digested by wet ashing and microwave digestion. The microwave digestion method offered best results and was successfully carried out for all samples. The results agreed well with the literature values.

diovascular disease and certain cancers.

Different instrumental techniques have been used for the determination of heavy metals in plant and food samples by atomic absorption spectrometry (AAS) $(5-16,17)$ and inductively coupled plasma optical emission spectrometry (ICP-OES) $(18,19)$. Microwave digestion methods are considered an accomplished sample pretreatment/dissolution procedure in analytical chemistry (8), which is also very fast and reduces sample contamination (20).

The aim of this paper was to determine trace level concentrations of some elements in soil, vegetable, and dried food samples obtained from the area of Sakarya, Turkey. The reliability of the method was verified by using certified (CRM) and standard reference materials (SRM). The analytical parameters show that microwave digestion provided better results than wet digestion. The trace element concentrations of all samples were determined by ICP-OES after microwave digestion.

\section{EXPERIMENTAL}

\section{Instrumentation}

A Spectro Arcos 165 optical emission spectrometer (SPECTRO Analytical Instruments, Kleve, Germany) was used for the determination of all elements. The ICP-OES instrumental operating conditions used were according to the manufacturer's recommendations and are listed in Table I. The Start D microwave closed system (Milestone, Sorisole-Bg, Italy) was used for digestion of the soil, vegetable, and dried food samples (maximum pressure $1450 \mathrm{psi}$ and maximum temperature is $300^{\circ} \mathrm{C}$ ). The ICPOES instrumental and operating conditions are listed in Table I.

\section{Reagents and Standard Solutions}

The chemicals used for all experiments were of ultra-pure reagents 
(E. Merck, Darmstadt, Germany). The acids $\mathrm{HCI}(37 \%), \mathrm{HNO}_{3}(65 \%)$, and $\mathrm{H}_{2} \mathrm{O}_{2}(30 \%)$ were of analytical reagent grade (E. Merck, Darmstadt, Germany). All glass utensils were soaked overnight in $10 \% \mathrm{HNO}_{3}$ and cleaned with distilled de-ionized Ultra High Quality (UHQ) water before use, chemical resistivity of $18 \mathrm{M} \Omega \cdot \mathrm{cm}$ (Millipore Corporation, Bedford, MA, USA). The ranges of the calibration curves were selected to be compatible with conventional concentrations (5-1000 $\left.\mu \mathrm{g} \mathrm{L}^{-1}\right)$ for the elements of the samples studied.

\section{Sample Collection}

Soil Samples

The soil samples were collected from agricultural areas in the counties of Sakarya City, Turkey. They were taken from a depth of roughly 0-15 cm, sieved through 230 mesh size $(63 \mu \mathrm{m})$ (Standard Testing Sieve, New Delhi, India), transferred to clean polyethylene bottles, agitated three times with deionized water, and stored in a refrigerator until analysis.
Vegetable, Fruits, Nuts, and Grain Samples

The vegetables with their green leaves were stored in polyethylene bottles. Dried fruit samples were purchased from local markets selling medicinal herbs. All samples (soils, vegetables, nuts, and grains as listed in Table II) were dried at $105^{\circ} \mathrm{C}$ for 24 hours, triturated, homogenized with an agate homogenizer, then stored in polyethylene bottles in a refrigerator until analysis.

\section{Wet Ashing Digestion}

\section{Sample Preparation}

A mixture of $\mathrm{HNO}_{3} / \mathrm{H}_{2} \mathrm{O}_{2}(6: 2)$ and $\mathrm{HCl} / \mathrm{HNO}_{3}(6: 2)$ was added to $1 \mathrm{~g}$ of sample, and placed on a hot plate (IKA, KS501D model, Germany) for solubilization at $130^{\circ} \mathrm{C}$ for four hours. The residue was filtered through a Whatman filter paper (Whatman Grade 589) and brought to $10-\mathrm{mL}$ volume with distilled deionized water. The element concentrations of the final solutions were determined by ICP-OES. Blanks were prepared in the same way.
TABLE I

ICP-OES Operating Parameters for the Determination of Elements

\begin{tabular}{ll}
\hline ICP-OES Instrument & SPECTRO ARCOS 165 \\
Viewing Height & $12 \mathrm{~mm}$ \\
Wavelengths (nm) & Co: 228.616, Cr: 267.716, \\
& Cu: $324.754, \mathrm{Fe}: 259.941$, \\
& $\mathrm{Mn}: 257.611, \mathrm{Ni} 231.604$, \\
& Se:196.090, Zn:213.856 \\
& 3 \\
Replicates & $1450 \mathrm{~W}$ \\
RF Power & Cyclonic \\
Spray Chamber & Modified Lichte Model \\
Nebulizer & $0.8 \mathrm{~L} / \mathrm{min}$ \\
Nebulizer Flow & Quartz, fixed, \\
Plasma Torch & $3.0-\mathrm{mm}$ injector tube \\
& $50 \mathrm{sec}$ per replicate \\
Replicate Read Time & $13 \mathrm{~L} / \mathrm{min}$ \\
Plasma Gas Flow & $0.7 \mathrm{~L} / \mathrm{min}$ \\
Auxiliary Gas Flow & $2.0 \mathrm{~mL} / \mathrm{min}$ \\
Sample Aspiration Rate & $25 \mathrm{rpm}$ \\
Sample Pump Rate &
\end{tabular}

\section{Microwave Digestion}

\section{Soil Sample Preparation}

The soil samples $(0.25 \mathrm{~g})$ were placed into reaction vessels (100 $\mathrm{mL}$ ) and digested with $\mathrm{HCl} / \mathrm{HNO}_{3}$ (6:2) in the microwave digestion system. Digestion conditions for the microwave system are given in Table III. After cooling, the final solutions were brought to $10 \mathrm{~mL}$ volume with distilled de-ionized water.

\section{Vegetable Sample Preparation}

The vegetable samples $(0.25 \mathrm{~g})$ were placed into reaction vessels (100 mL) and digested with $\mathrm{HNO}_{3}$ $\mathrm{H}_{2} \mathrm{O}_{2}(6: 2)$ in the microwave digestion system. The digestion conditions are given in Table III. After cooling, the final solutions were brought to $10-\mathrm{mL}$ volume with distilled deionized water.

\section{Dried Fruit, Nut, and Grain Sample Preparation}

Dried fruit, nut, and grain samples of $1.0 \mathrm{~g}$ were placed into reaction vessels, then $100 \mathrm{~mL}$ and $8 \mathrm{~mL}$ of a freshly prepared mixture of
TABLE II

List of Different Foods and Vegetables Used for Analysis in this Study

\begin{tabular}{lll}
\hline Scientific Name & English & Turkish \\
\hline Actinidia & kiwi & kivi \\
Allium cepaL & green onion & yesil sogan \\
Allium porrumL. & leek & pirasa \\
Beta vulgaris L. var. condivitaalef & beetroot & pancar \\
Corylusavellana & hazelnut & findik \\
Cydoniaoblonga & quince & ayva \\
Erucavesicaria subsp. sativa & arugula & roka \\
Juglans & walnut & ceviz \\
Lactuca sativa L. & lettuce & marul \\
Malusdomestica & apple & elma \\
Petroselinumbortense & parsley & maydanoz \\
Prunusdomestica & prune & kuruerik \\
Solanumlycopersicum & tomato & domates \\
Spinaciaoleracea L. & spinach & 1spanak \\
Triticum & wheat & bugday \\
Zea mays & corn & misir \\
\hline
\end{tabular}


concentrated $\mathrm{HCl} / \mathrm{HNO}_{3}(6: 2)$ was added and left standing for $10 \mathrm{~min}$ utes. The digestion conditions for the microwave system are given in Table III. After cooling, the final solutions were brought to $10-\mathrm{mL}$ volume with $1 \mathrm{M} \mathrm{HNO}_{3}$. The blanks were prepared in the same way, but without the sample.

\section{Certified (CRM) and Standard Reference Material (SRM)}

Recovery, precision, and analytical reproducibility of the proposed method were determined using certified reference material CRM 7001 Light Sandy Soil - Trace Elements (Czech Metrology Institute) and standard reference material NIST SRM 1515 Apple Leaves (National Institute for Standards and Technology, Gaithersburg, MD, USA). Each sample was prepared in duplicate, including the blank. The CRM and SRM analysis results were all within the 95\% confidence limit (Tables IV

\begin{tabular}{|c|c|c|}
\hline \multicolumn{3}{|c|}{$\begin{array}{c}\text { TABLE III } \\
\text { Operating Conditions } \\
\text { for Samples in } \\
\text { Microwave Digestion System }\end{array}$} \\
\hline Steps & $\begin{array}{l}\text { Time } \\
\text { (min) }\end{array}$ & $\begin{array}{c}\text { Power } \\
\text { (W) }\end{array}$ \\
\hline \multicolumn{3}{|c|}{ Soil samples } \\
\hline 1 & 10 & 800 \\
\hline 2 & 15 & 800 \\
\hline Vent & 11 & - \\
\hline \multicolumn{3}{|c|}{ Vegetable samples } \\
\hline 1 & 2 & 250 \\
\hline 2 & 2 & 0 \\
\hline 3 & 6 & 250 \\
\hline 4 & 5 & 400 \\
\hline 5 & 8 & 600 \\
\hline Vent & 11 & - \\
\hline \multicolumn{3}{|c|}{ Dried fruit samples } \\
\hline 1 & 2 & 250 \\
\hline 2 & 2 & 0 \\
\hline 3 & 6 & 250 \\
\hline 4 & 5 & 400 \\
\hline 5 & 8 & 550 \\
\hline Vent & 8 & - \\
\hline
\end{tabular}

and V) and compared well with the real sample analyses.

\section{RESULTS AND DISCUSSION}

The relative standard deviations were less than $10 \%$ for all investigated elements. All of the data were subjected to statistical analysis and correlation matrices were produced to examine the inter-relationship between the trace metal concentrations. The Student's $t$-test was used in this study $(\mathrm{p}<0.05)$.

A comparison of the results of the wet and microwave digestion methods shows that there are no statistically crucial differences (Table V). However, in comparison to wet digestion, the microwave sample digestion is simple, fast, and accurate for the ICP-OES determination of $\mathrm{Co}, \mathrm{Cr}, \mathrm{Cu}, \mathrm{Fe}, \mathrm{Mn}, \mathrm{Ni}$, Se, and $\mathrm{Zn}$ in soil, vegetable, nut, and grain samples with high recoveries (Table IV). Method validation was performed by the analysis of the means of the certified and standard reference materials.

The recovery values were quantitative for the microwave digestion method. The performance of each digestion method was compared by using two acid mixtures: $\mathrm{HNO}_{3} / \mathrm{H}_{2} \mathrm{O}_{2}(6: 2)$ and $\mathrm{HCI} / \mathrm{HNO}_{3}$ (6:2). The accuracy of the results was verified (Tables IV and V) by analyzing of certified and standard reference materials. The optimized method was carried out for some food samples.

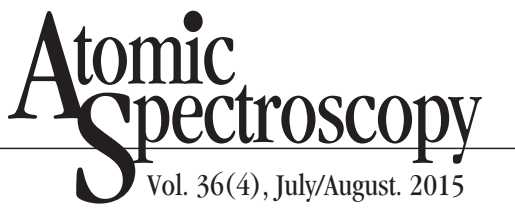

The trace element concentrations of the real samples are listed in Table VI for the soil, Table VII for the vegetable, and Table VIII for the food samples and are discussed below.

\section{Soil Sample Analysis}

The element concentrations in the soil samples were 0.6-1.7 (Co), 4.2-8.5 (Cr), 2.5-8.5 (Cu), 46.2-69.9 (Mn), 4.7-7.6 (Ni), and 5.3-9.4 (Zn) $\mu \mathrm{g} \mathrm{g}^{-1}$ (Table VI). In accordance with these data, manganese was found to be present at the highest concentration, and selenium below the detection limit. According to E.U. recommendations (21), the maximum allowable concentrations (MAC) for cobalt in soil samples are in the $0.5-65 \mu \mathrm{g} \mathrm{g}^{-1}$ range. Thus, the cobalt levels of this study were within normal limits in all soil samples. The total chromium concentration was 100 $\mu \mathrm{g} \mathrm{g}^{-1}$ and is within the accepted limits for all samples. The maximum allowable levels of copper are within the 2-250 $\mu \mathrm{g} \mathrm{g}^{-1}$ ranges (22). The maximum allowable concentrations of manganese are within the 164-1330 $\mathrm{g} \mathrm{g}^{-1}$ range (23). Thus, the Mn levels in this study are lower than the maximum allowable concentration limits. The nickel levels were within the $100 \mu \mathrm{g} \mathrm{g}^{-1}$ limit, and the zinc levels were also in the accepted limit of 1-900 $\mu \mathrm{g} \mathrm{g}^{-1}$ (22).

\section{TABLE IV}

Certified and Found Values $\left(\mu \mathrm{g} \mathrm{g}^{-1}\right)$ of Total Element Concentrations in CRM 7001 Light Sandy Soil - Trace Elements

\begin{tabular}{lccc}
\hline Elements & Certified value & Found Value & Recovery (\%) \\
\hline $\mathrm{Co}$ & $9.66 \pm 0.61$ & $10.10 \pm 1.50$ & 104.6 \\
$\mathrm{Cr}$ & $71.9 \pm 5.9$ & $72.2 \pm 3.1$ & 100.4 \\
$\mathrm{Cu}$ & $28.9 \pm 0.8$ & $28.1 \pm 0.5$ & 97.2 \\
$\mathrm{Mn}$ & $479 \pm 18$ & $483 \pm 10$ & 100.8 \\
$\mathrm{Ni}$ & $31.8 \pm 1.2$ & $32.4 \pm 1.3$ & 101.9 \\
$\mathrm{Zn}$ & $108.0 \pm 3.5$ & $109.0 \pm 3.6$ & 100.9 \\
\hline
\end{tabular}


Vegetable, Nuts, Grain Sample Analysis

The element concentrations of all vegetable samples were $0.2-1.1$ $\mu \mathrm{g} \mathrm{g}^{-1}$ (Cu), 27.2-114.6 $\mu \mathrm{g} \mathrm{g}^{-1}$ (Fe), 3.8-6.5 $\mu \mathrm{g} \mathrm{g}^{-1}(\mathrm{Mn})$, and 2.1-8.9 (Zn) $\mu \mathrm{g} \mathrm{g}^{-1}$ (Table VII). While iron was present at the highest concentration, cobalt, chromium, nickel, and selenium were found under the detection limit. The reported acceptable values for copper were within the $2.5-16 \mu \mathrm{g} \mathrm{g}^{-1}$ range (24), but in the samples of this study they were lower. The manganese content varied from 3.8 (parsley) to $6.5 \mu \mathrm{g} \mathrm{g}^{-1}$ (lettuce), while the levels reported in the literature are within the 9-16.6 $\mathrm{ug} \mathrm{g}^{-1}$ range for all food categories in India (25). Similarly, the Mn levels in the present study were lower than those found in the literature (25).

\section{TABLE V}

Comparison of Digestion Conditions of Elemental Concentrations $\left(\mu \mathrm{g} \mathrm{g}^{-1}\right)$

Using NIST SRM 1515 Apple Leaves (average \pm S.D., N=3)

\begin{tabular}{|c|c|c|c|c|c|c|c|}
\hline \multirow{3}{*}{$\begin{array}{l}\text { Ele- } \\
\text { ments }\end{array}$} & \multirow{3}{*}{$\begin{array}{c}\text { Certified } \\
\text { Value }\end{array}$} & \multicolumn{2}{|c|}{ Microwave Digestion } & \multicolumn{4}{|c|}{ Wet Digestion } \\
\hline & & $\begin{array}{l}\mathrm{HNO}_{3} / \mathrm{H}_{2} \mathrm{O}_{2} \\
\quad(6: 2)\end{array}$ & $\begin{array}{c}\text { Recovery } \\
(\%)\end{array}$ & $\begin{array}{c}\mathrm{HNO}_{3} / \mathrm{H}_{2} \mathrm{O}_{2} \\
(6: 2)\end{array}$ & $\begin{array}{c}\text { Recovery } \\
\text { (\%) }\end{array}$ & $\begin{array}{c}\mathrm{HCI} / \mathrm{HNO}_{3} \\
(6: 2)\end{array}$ & $\begin{array}{c}\text { Recovery } \\
(\%)\end{array}$ \\
\hline & & \multicolumn{2}{|c|}{ Found Value } & \multicolumn{4}{|c|}{ Found Value } \\
\hline Co & 0.09 & $0.10 \pm 0.01$ & 111 & $0.12 \pm 0.02$ & 133 & $0.11 \pm 0.01$ & 122 \\
\hline $\mathrm{Cr}$ & 0.30 & $0.35 \pm 0.03$ & 117 & $0.37 \pm 0.02$ & 123 & $0.36 \pm 0.01$ & 120 \\
\hline $\mathrm{Cu}$ & 5.64 & $5.58 \pm 1.12$ & 99 & $5.53 \pm 1.36$ & 98 & $5.53 \pm 2.10$ & 98 \\
\hline $\mathrm{Fe}$ & 83 & $82.17 \pm 3.45$ & 99 & $80.51 \pm 2.78$ & 97 & $81.34 \pm 3.10$ & 97 \\
\hline Mn & 54 & $52.92 \pm 2.78$ & 98 & $51.64 \pm 3.65$ & 96 & $53.23 \pm 4.12$ & 99 \\
\hline $\mathrm{Ni}$ & 0.91 & $0.90 \pm 0.13$ & 99 & $0.92 \pm 1.03$ & 101 & $0.89 \pm 0.09$ & 98 \\
\hline Se & 0.050 & $0.048 \pm 0.003$ & 96 & $0.044 \pm 0.001$ & 88 & $0.045 \pm 0.002$ & 90 \\
\hline $\mathrm{Zn}$ & 12.5 & $12.38 \pm 0.69$ & 99 & $12.25 \pm 1.12$ & 98 & $12.63 \pm 2.19$ & 101 \\
\hline
\end{tabular}

TABLE VI

Concentrations $\left(\mu \mathrm{g} \mathrm{g}^{-1}\right)$ of Trace Metals in Soil Samples $(\mathrm{N}=3)$

\begin{tabular}{lccccccc}
\hline Regions & $\mathrm{Co}$ & $\mathrm{Cr}$ & $\mathrm{Cu}$ & $\mathrm{Mn}$ & $\mathrm{Ni}$ & $\mathrm{Se}$ & $\mathrm{Zn}$ \\
\hline Pamukova & $0.6 \pm 0.1$ & $6.3 \pm 1.2$ & $7.4 \pm 1.3$ & $48.5 \pm 3.8$ & $4.7 \pm 0.8$ & $\mathrm{BDL}$ & $5.8 \pm 0.9$ \\
Pamukova & $0.6 \pm 0.1$ & $7.4 \pm 1.3$ & $3.6 \pm 0.8$ & $52.3 \pm 4.1$ & $5.5 \pm 0.9$ & $\mathrm{BDL}$ & $6.6 \pm 0.9$ \\
Ferizli & $1.1 \pm 0.1$ & $8.5 \pm 1.3$ & $2.9 \pm 0.6$ & $67.2 \pm 4.8$ & $6.8 \pm 1.1$ & $\mathrm{BDL}$ & $8.4 \pm 1.4$ \\
Hendek & $0.7 \pm 0.1$ & $7.4 \pm 1.4$ & $2.6 \pm 0.4$ & $52.8 \pm 3.9$ & $6.5 \pm 1.0$ & $\mathrm{BDL}$ & $9.4 \pm 1.5$ \\
Adapazarı & $1.1 \pm 0.1$ & $5.3 \pm 1.3$ & $7.1 \pm 1.2$ & $69.9 \pm 5.1$ & $6.1 \pm 1.2$ & $\mathrm{BDL}$ & $7.5 \pm 1.4$ \\
Pamukova & $0.8 \pm 0.1$ & $6.2 \pm 1.5$ & $2.8 \pm 0.6$ & $58.4 \pm 4.6$ & $5.8 \pm 0.9$ & $\mathrm{BDL}$ & $6.3 \pm 1.5$ \\
Geyve & $1.7 \pm 0.2$ & $4.2 \pm 1.0$ & $3.2 \pm 0.9$ & $59.0 \pm 4.7$ & $6.1 \pm 1.2$ & $\mathrm{BDL}$ & $6.7 \pm 1.3$ \\
Geyve & $1.4 \pm 0.3$ & $7.6 \pm 1.3$ & $3.6 \pm 0.9$ & $63.5 \pm 5.0$ & $5.3 \pm 0.9$ & $\mathrm{BDL}$ & $8.9 \pm 1.8$ \\
Geyve & $0.7 \pm 0.1$ & $5.3 \pm 1.2$ & $8.5 \pm 1.2$ & $53.4 \pm 4.3$ & $6.5 \pm 1.0$ & $\mathrm{BDL}$ & $8.6 \pm 1.4$ \\
Sögütlü & $1.5 \pm 0.2$ & $8.2 \pm 1.6$ & $4.4 \pm 1.1$ & $46.2 \pm 3.6$ & $6.3 \pm 1.1$ & $\mathrm{BDL}$ & $5.6 \pm 0.9$ \\
Sögütlü & $1.4 \pm 0.2$ & $8.1 \pm 1.4$ & $2.5 \pm 0.9$ & $60.4 \pm 4.7$ & $7.6 \pm 1.2$ & $\mathrm{BDL}$ & $6.8 \pm 1.2$ \\
\hline BDL: B & & & & & & &
\end{tabular}

BDL: Below detection limit.

TABLE VII

Concentrations $\left(\mu \mathrm{g} \mathrm{g}^{-1}\right)$ of Trace Metals in Some Vegetable Samples $(\mathrm{N}=3)$

\begin{tabular}{ccccccccc}
\hline Sample & $\mathrm{Co}$ & $\mathrm{Cr}$ & $\mathrm{Cu}$ & $\mathrm{Fe}$ & $\mathrm{Mn}$ & $\mathrm{Ni}$ & $\mathrm{Se}$ & $\mathrm{Zn}$ \\
\hline Arugula & $\mathrm{BDL}$ & $\mathrm{BDL}$ & $0.5 \pm 0.1$ & $27.2 \pm 3.1$ & $4.4 \pm 0.7$ & $\mathrm{BDL}$ & $\mathrm{BDL}$ & $3.7 \pm 0.3$ \\
Lettuce & $\mathrm{BDL}$ & $\mathrm{BDL}$ & $1.1 \pm 0.3$ & $114.6 \pm 9.3$ & $6.5 \pm 1.4$ & $\mathrm{BDL}$ & $\mathrm{BDL}$ & $2.1 \pm 0.1$ \\
Parsley & $\mathrm{BDL}$ & $\mathrm{BDL}$ & $0.4 \pm 0.1$ & $35.5 \pm 4.5$ & $3.8 \pm 0.6$ & $\mathrm{BDL}$ & $\mathrm{BDL}$ & $2.2 \pm 0.2$ \\
Scallion & $\mathrm{BDL}$ & $\mathrm{BDL}$ & $0.20 \pm 0.04$ & $73.1 \pm 2.1$ & $4.7 \pm 0.3$ & $\mathrm{BDL}$ & $\mathrm{BDL}$ & $2.4 \pm 0.3$ \\
Spinach & $\mathrm{BDL}$ & $\mathrm{BDL}$ & $0.6 \pm 0.1$ & $53.1 \pm 4.7$ & $4.2 \pm 0.1$ & $\mathrm{BDL}$ & $\mathrm{BDL}$ & $8.9 \pm 1.6$ \\
\hline
\end{tabular}

BDL: Below detection limit. 
Iron concentrations ranged (25) from 27.2 (arugula) to $114.6 \mu \mathrm{g} \mathrm{g}^{-1}$ (lettuce) for the vegetables. The iron levels for lettuce were found to be above the accepted limits of $425 \mu \mathrm{g} \mathrm{g}^{-1}$ for soils. In comparison to the suggested levels of the Food and Agriculture Organization (FAO)-World Health Organization (WHO) (26), the zinc levels were below the accepted FAO-WHO limits of $100 \mathrm{mg} \mathrm{kg}^{-1}$ (26).

Heavy metals in vegetables are absorbed from the soil, polluted air, and water. It has been reported that higher amounts of heavy metals accumulate mostly in the leaves of leafy vegetables (27).

\section{Food Sample Analysis}

The evident toxic and trace elements are very significant for human biology (28-29). Table VIII lists the trace element concentrations of all food samples which were as follows: $0.04-0.94 \mu \mathrm{g} \mathrm{g}^{-1}$ (Co), 0.24-5.64 $\mu \mathrm{g} \mathrm{g}^{-1}$ (Cr), 2.55-15.92 $\mu \mathrm{g} \mathrm{g}^{-1}(\mathrm{Cu}), 4.82-37.55$ $\mu \mathrm{g} \mathrm{g}^{-1}$ (Fe), 1.12-30.17 $\mu \mathrm{g} \mathrm{g}^{-1}$ (Mn), $0.43-2.27 \mu \mathrm{g} \mathrm{g}^{-1}(\mathrm{Ni}), 0.03-0.94 \mu \mathrm{g}$ $\mathrm{g}^{-1}$ (Se), and 2.93-20.91 $\mu \mathrm{g} \mathrm{g}^{-1}(\mathrm{Zn})$. In accordance with these data, iron has the highest concentration, fol- lowed by manganese, zinc, and iron.

According to the Turkish Food Codex (30), the MAC of cobalt in some food samples is $0.2 \mathrm{mg} \mathrm{kg}^{-1}$. Chromium concentrations in different fruits from Pakistan (31) have been reported to be within the range of $1.48-6.43 \mathrm{mg} \mathrm{kg}^{-1}$ wet weight and copper concentrations in dried fruit samples from Pakistan within the range of 3.90-25.0 $\mu \mathrm{g} \mathrm{g}^{-1}$ dry weight (32). In fruits sold at Egyptian markets, the Co concentrations ranged from $1.22-18.3 \mathrm{mg}$ $\mathrm{kg}^{-1}$ (33) and from 1.68-4.52 $\mu \mathrm{g} \mathrm{g}^{-1}$ dry weight from fruits sold in Kayseri, Turkey (5).

The concentration of iron was found to be in the 4.82-37.55 $\mu \mathrm{g} \mathrm{g}^{-1}$ range for all of the samples in this study. The allowable iron concentration in dried fruits from Pakistan (32) was in the range of 19.0-45.0

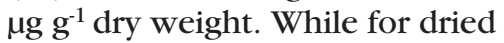
fruits from Kayseri, Turkey (5), it was found to be $6.76-64.1 \mu \mathrm{g} \mathrm{g}^{-1}$. For food it was in the $15 \mathrm{mg} \mathrm{kg}^{-1}$ range and is in accordance with the Turkish Food Codex (34).

The official allowable manganese values are within the $2.14-17.23$

\section{Atomic Apectroscopy 1 Vol. 36(4), July/August. 2015}

$\mu \mathrm{g} \mathrm{g}^{-1}$ range for dried fruits from Pakistan (32) and 4.74-25.5 $\mu \mathrm{g} \mathrm{g}^{-1}$ from Turkey (5). In this study, the manganese level was found within the $1.12-30.17 \mu \mathrm{g} \mathrm{g}^{-1}$ range for quince and walnut samples, respectively. The U.S. National Academy of Sciences suggested 2.5-5.0 mg as the daily maximum for manganese, while the WHO recommendations are $2-9 \mathrm{mg}$ daily (35). Nickel allowable values are within the 1.0-8.9 $\mathrm{mg} \mathrm{kg}^{-1}$ range in fruits from Pakistan (31). The concentration of nickel for samples analyzed in this study was found within the $0.43-2.27 \mu \mathrm{g} \mathrm{g}^{-1}$ range, whereas the MAC of nickel in some food samples was $0.2 \mathrm{mg} \mathrm{kg}^{-1}$ (30).

In this study, the concentration of selenium was found within the $0.03-0.94 \mu \mathrm{g} \mathrm{g}^{-1}$ range. The daily MAC intake of selenium in Turkey is $30 \mu \mathrm{g} \mathrm{day}^{-1}$ (36), although the selenium need of adult males and females is computed to be $55 \mu \mathrm{g}$ day $^{-1}$ (37). According to the Turkish Food Codex (34), the MAC of zinc in food is $5 \mathrm{mg} \mathrm{kg}^{-1}$. The lowest and highest levels of zinc reported were 64.2 and $65.8 \mu \mathrm{g} \mathrm{g}^{-1}$, respectively, in spices, dried fruit, and nuts from Pakistan (32).

TABLE VIII

Element Concentrations $\left(\mu \mathrm{g} \mathrm{g}^{-1}\right)$ in Some Food Samples $(\mathrm{N}=3)$

\begin{tabular}{lcccccccc}
\hline Sample & $\mathrm{Co}$ & $\mathrm{Cr}$ & $\mathrm{Cu}$ & $\mathrm{Fe}$ & $\mathrm{Mn}$ & $\mathrm{Ni}$ & $\mathrm{Se}$ & $\mathrm{Zn}$ \\
\hline Bulgur & $0.84 \pm 0.20$ & $1.16 \pm 0.25$ & $3.48 \pm 0.07$ & $17.69 \pm 3.14$ & $15.32 \pm 3.25$ & $1.70 \pm 0.05$ & $0.09 \pm 0.03$ & $16.51 \pm 2.47$ \\
Dried kiwi & $0.59 \pm 0.10$ & $0.83 \pm 0.16$ & $7.11 \pm 2.10$ & $7.82 \pm 2.14$ & $20.29 \pm 2.45$ & $1.90 \pm 0.10$ & $0.10 \pm 0.03$ & $10.87 \pm 1.65$ \\
Dried tomato & $0.31 \pm 0.06$ & $3.80 \pm 0.36$ & $10.30 \pm 2.14$ & $37.55 \pm 6.45$ & $4.83 \pm 1.12$ & $1.75 \pm 0.16$ & $0.31 \pm 0.04$ & $12.71 \pm 1.45$ \\
Hazelnut & $0.79 \pm 0.18$ & $0.49 \pm 0.04$ & $11.49 \pm 2.41$ & $18.61 \pm 2.78$ & $26.79 \pm 3.48$ & $1.41 \pm 0.25$ & $0.18 \pm 0.04$ & $7.18 \pm 1.18$ \\
Prune & $0.82 \pm 0.14$ & $1.73 \pm 0.14$ & $2.55 \pm 0.16$ & $16.77 \pm 3.14$ & $2.69 \pm 0.12$ & $0.98 \pm 0.14$ & $0.76 \pm 0.06$ & $6.94 \pm 2.12$ \\
Pumpkin & & & & & & & & \\
shell & $0.08 \pm 0.02$ & $0.24 \pm 0.04$ & $4.48 \pm 1.14$ & $4.82 \pm 1.13$ & $4.35 \pm 0.16$ & $0.46 \pm 0.03$ & $0.03 \pm 0.01$ & $3.54 \pm 0.15$ \\
Pumpkin & & & & & & & \\
seeds & $0.41 \pm 0.03$ & $1.40 \pm 0.23$ & $15.92 \pm 2.36$ & $22.89 \pm 4.45$ & $24.15 \pm 1.78$ & $1.49 \pm 0.14$ & $0.94 \pm 0.04$ & $20.91 \pm 1.87$ \\
Quince & $0.04 \pm 0.02$ & $1.50 \pm 0.17$ & $2.83 \pm 0.16$ & $30.41 \pm 3.14$ & $1.12 \pm 0.02$ & $0.43 \pm 0.01$ & $0.07 \pm 0.01$ & $2.93 \pm 0.08$ \\
Tomato & $0.57 \pm 0.11$ & $5.64 \pm 0.42$ & $15.21 \pm 3.67$ & $35.54 \pm 3.41$ & $5.79 \pm 2.54$ & $2.15 \pm 0.25$ & $0.36 \pm 0.08$ & $15.07 \pm 2.65$ \\
Walnut & $0.94 \pm 0.15$ & $1.06 \pm 0.07$ & $7.26 \pm 1.36$ & $29.72 \pm 4.21$ & $30.17 \pm 3.65$ & $2.27 \pm 0.14$ & $0.04 \pm 0.02$ & $9.14 \pm 2.10$ \\
\hline
\end{tabular}




\section{CONCLUSION}

In this study, it was shown that microwave digestion is more accurate, simpler, and faster than wet digestion in the ICP-OES determination of the trace elements $\mathrm{Co}, \mathrm{Cr}$, $\mathrm{Cu}, \mathrm{Fe}, \mathrm{Mn}, \mathrm{Ni}, \mathrm{Se}$, and $\mathrm{Zn}$ in soil, vegetable, nut, and grain samples. The recovery values for these elements using microwave digestion were quantitative. The soil and vegetable samples contained heavy metals at lower than the tolerable levels recommended by the Joint FAO/WHO Expert Committee on Food Additives. The elemental levels of the nut and grain samples were found to be acceptable for human consumption with regard to their nutritional and toxic values. The analytical results were verified by analysis of certified and standard reference materials and were found to be within the $95 \%$ confidence limit.

\section{ACKNOWLEDGMENT}

This work was supported by the Sakarya University Scientific Research Foundation (Project Number: 201250-02-021).

$\overline{\text { Received October 31, } 2014 .}$

\section{REFERENCES}

1. M. Tuzen, Microchem. J. 74(3), 289 (2003).

2. N. Ozcan and H. Altundag, Bull. Chem. Soc. Ethiopia. 27(2), 205 (2013).

3. M.K. Jamali, T.G. Kazi, M.B. Arain, H.I. Afridi, N. Jalbani, and A.R. Memon, J. Agronomy Crop Sci. 193(3), 218 (2007).

4. H. Altundag, M.S. Dundar, and C.S. Keskin, Eco. Chem. Eng. S. 20(2), 257 (2013).

5. A. Duran, M. Tuzen, and M. Soylak, Inter. J. of Food Sci. Nutr. 59(7-8), 581 (2008).

6. M. Tuzen, and M. Soylak, J. Food Drug Anal. 13(4), 343 (2005).
7. M.S. Dundar, and H. Altundag, Trace. Elem. Electroly. 19(2), 55 (2002).

8. H. Altundag, and M. Tuzen, Food Chem. Tox. 49(11), 2800 (2011).

9. T.G. Kazi, M.K. Jamali, M.B. Arain, H.I. Afridi, N. Jalbani, A. Raja, R.A. Sarfraz, and R. Ansari, J. Hazard. Mater. 161, 1391 (2009).

10. S. Tokalioglu, S. Kartal, and G. Birol, Environ. Monit. Assess. 5(3), 468 (2003).

11. L.A. Sargeant, K.T. Khaw, S. Bingham, N.E. Day, R.N. Luben, S.Oakes, A. Welch, and N.J. Wareham, J. Clin. Nutr. 55(5), 342 (2001).

12. A. Aberoumand, and S.S. Deokule, Food. Anal. Method. 2(2), 116 (2009).

13. L.A. Bazzano, J. He, L.G. Ogden, C.M. Loria, S. Vupputuri, L. Myers, and P.K. Whelton, Amer. J. Clin. Nutr. 76(1), 93 (2002).

14. WHO, World Health Org. Diet Nutr. and Prevent. of Chr. Dis. (2003).

15. P. Ekholm, H. Reinivuo, P. Mattila, H. Pakkala, J. Koponen, A. Happonen, J. Hellstrom, and M.L. Ovaskainen, J. Food Comp. Anal. 20, 487 (2007).

16. H. Altundag, M.S. Dundar, S. Doganci, M. Celik, and M. Tuzen, J. AOAC Int. 96, 166 (2013).

17. M.S. Dundar, and H. Altundag, Environ. Monitor. Assess. 128(1-3), 177 (2006)

18. M. Bettinelli, G.M. Beone, S. Spezia, and C. Baffi, Anal. Chim. Acta. 424, 289 (2000).

19. E. Altintig, H. Altundag, and M. Tuzen, Bull. Chem. Soc. Ethiopia.28(1), 9 (2014).

20. D. Bakircioglu, Y.B. Kurtulus, and G. Ucar, Food Chem. Tox. 49(1), 202 (2011).

21. U. Altinbas, H. Hakerlerler, D. Anac, H. Tuncay and B. Okur, E.U. Rektör. Araş. Fonu Proje No:91 (1994).

22. B.J. Alloway, Record Number: 19901948863, 33 (1990).

23. A. Kabata-Pendias, and H. Pendias, CRC Press. Boca Raton, Florida, USA. 365 (1992).
24. T.E. Bahemuka, and E.B. Mubofu, Food Chem. 66(1), 63 (1999).

25. T.R. Chowdhury, H. Tokunaga, and M. Ando, Sci. Total. Environ. 308(1-3), 15 (2003).

26. WHO, Tech. Report Series No. 683. (1982).

27. D. Demirezen, and A. Aksoy, J. Food Qual. 29, 252 (2006).

28. T.G. Kazi, H.I. Afridi, N. Kazi, M.K. Jamali, M.B. Arain, R.A. Sarfraz, N. Jalbani, R. Ansari, A.Q. Shah, A.R. Memon, and G.A. Khandhro, Clin. Chim. Acta. 389(1-2), 114 (2008).

29. A.R. Memon, T.G. Kazi, H.I. Afridi, M.K. Jamali, M.B. Arain, N. Jalbani, and N. Syed, Clin. Chim. Acta. 379(1-2), 66 (2007).

30. Anonymous, Off. Gazette Iss: 24908 (2002).

31. A. Zahoor, M. Jaffar, and M. Saqib, Nutr. Food Sci. 33(5), 203 (2003).

32. A. Sattar, M. Wahid, and S.K. Durrani, Plant Foods for Human Nutr. 39, 279 (1989).

33. M.A. Radwan, and A.K. Salama, Food Chem. Tox. 44(8), 1273 (2006).

34. S. Saracoglu, M. Tuzen, and M. Soylak, J. Hazard. Mater. 167(1-3), 647 (2009).

35. WHO, World Health Org. Qual. Direct. Pot. Water, 197 (1994).

36. L.H. Foster, and S. Sumar, Crit. Rev. Food Sci. Nutr. 37(3), 211 (1997).

37. RDA, Recom. Diet. Allow. Nation. Acad. Press Washington, DC. (1989). 